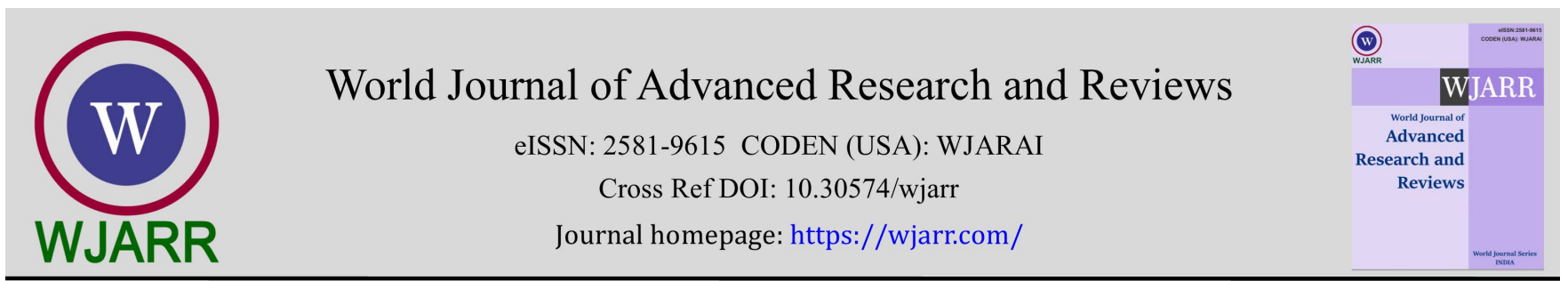

(REVIEW ARTICLE)

Check for updates

\title{
Generating and analyzing Terrain characteristics from Shuttle Radar Topographic Mission (SRTM), DEM
}

Ugbelase Vincent Nwacholundu *, Igbokwe Joel Izuchukwu, Emengini Josephine Ebele, Ejikeme Joseph Onyedika and Igbokwe Esomchukwu Chinagorom

Department of Surveying \& Geoinformatics, Nnamdi Azikiwe University, Awka, Anambra, Nigeria.

World Journal of Advanced Research and Reviews, 2021, 10(03), 198-206

Publication history: Received on 05 May 2021; revised on 08 June 2021; accepted on 11 June 2021

Article DOI: https://doi.org/10.30574/wjarr.2021.10.3.0272

\begin{abstract}
Terrain analysis is the quantitative analysis of topographic surfaces. The purpose of a digital terrain system is to provide the digital representation of terrain so that environmental problem like soil erosion may be approached accurately and efficiently through automated means. Traditionally this was (and still is!) being done manually by using topographic/contour maps. With the availability of Digital Elevation Models (DEM) and GIS tools, watershed properties can be extracted by using automated procedures. Remote Sensing and Digital elevation models (DEMs) are known to be very useful data sources for the automated delineation of flow paths, sub watersheds and flow networks for hydrologic modelling and watershed characterization. The digital terrain model was extracted from a 90m resolution Shuttle Radar Topographic Mission (SRTM) of the study area. The SRTM data was corrected by removing voids, striping, tree offsets and random noise. The SRTM DEM data was projected from geographic coordinate WGS 84 to UTM zone 32 of the study area. The 3-D analysis tool of the ArcGIS 10.1 was used for this process. The DEM was processed to obtain the Slope, Contour, Flow direction, Flow accumulation, Flow length, Stream power Index of the study area. The study proved that SRTM elevation dataset has the ability to obviate the lack of terrain data for hydrologic modelling using ArcGIS where appropriate data for terrain modelling and simulation of hydrological processes is unavailable.
\end{abstract}

Keywords: SRTM; DEM; ArcGIS; Terrain

\section{Introduction}

In hydrology, the prediction of peak flow and the simulation of flood hydrographs in a stream or river is a very complex process, because the hydrological variablesvarybothinspaceandtimeasafunctionofthemeteorologicalinputs, spatial variability of topography, land use and soil types. Traditional hydrological lumped models use transfer functions relating statistical properties of rainfall in river basins to observed runoff and hydrographs. However, these models do not consider distributed rainfall and basin characteristics, and thus provide little or no spatially distributed information. Conventional topographic mapping technologies have produced maps of uneven quality: some with astounding accuracy, some far less adequate. The map products derived from these databases have demonstrated the idiosyncrasies of these conventional topographic data: The maps are at a variety of scales and resolutions, often referenced to countryspecific datum and thus are inconsistent across national boundaries. Further- more, the global coverage has been uneven. In many parts of the world, particularly cloudy parts of South America and Africa, very little high-quality topographic data exist.

The emergence, in the 1990s, of synthetic aperture radar (SAR) interferometry $(1,2,3,4)$ placed the possibility of efficiently and affordably creating a global digital elevation model. The Shuttle Radar Topography Mission (SRTM)

\footnotetext{
* Corresponding author: Ugbelase VN

Department of Surveying \& Geoinformatics, Nnamdi Azikiwe University, Awka, Anambra, Nigeria.

Copyright $(2021$ Author(s) retain the copyright of this article. This article is published under the terms of the Creative Commons Attribution Liscense 4.0.
} 
demonstrated the power of the new technique. The Shuttle Radar Topographic Mission was launched in February 2000. The mission obtained elevation data on a near global scale to generate the most complete high resolution digital topographic database of the Earth. The project was a joint project of NASA, the U.S. National Geospatial Agency (NGA) and the German and Italian Space Agencies. It used dual antennas to acquire interferometric radar data (IFSAR), processed to digital topographic at 1 arc-sec resolution (5). The increasing availability of high-resolution digital elevation models (DEM) from reliable sources like the Shuttle Radar Topography Mission (SRTM) has made development and application of procedures for automated landform identification increasingly feasible and cost effective.

The purpose of a digital terrain system is to provide the digital representation of terrain so that environmental problem like soil erosion may be approached accurately and efficiently through automated means. Topographic attributes, including specific catchment area, slope, aspect, plan curvature can be calculated and used to predict spatial patterns of soil water content and soil erosion, solar radiation estimation, spatial distribution of soil physical and chemical properties, spatial distribution of vegetation and prediction of vegetation types.

A Digital Elevation Model (DEM) is the source of the primary data used as a source of topographic surfaces information alone (6), for landscape modelling $(7,8)$ as data layers in a GIS (9) and as ancillary data in remote sensing image analysis. Digital Terrain Models (DTM) has been used in geoscience application since the 1950s (10). In GIS, DTMs provide an opportunity to model, analyses and display phenomena related to topography. Indeed, DTMs include the spatial distribution of terrain attributes. The spatial distribution of topographic attributes can thus be used as a direct or indirect measure of spatial variability of these processes.

Digital terrains modelling encompasses the following general tasks (9):

\subsection{DTM generation}

Sampling of original terrain data, formation of relations among the diverse observations.

\subsection{DTM manipulation}

Modification and refinement of DTMs.

\subsection{DTM visualization}

Display of elements of DTM, information from DTM.

\subsection{DTM interpretation}

DTM analysis, information, extraction from DTMs.

\subsection{DTM application}

Development of appropriate application model for specific disciplines.

\section{Aim and Objectives of the Study}

The Aim of this study is to demonstrate the capability of the SRTM in conjunction with GIS technology to determine terrain variability.

The specific objectives include:

- $\quad$ Download the SRTM data from United State Geological Survey (USGS).

- Generate DEM of the study area from the SRTM

- Use the ArcGIS hydrology tool to extract some terrain characteristic maps of the study area.

\section{Study area}

Aniocha North local Government Area of Delta State is the study area. Aniocha North was created in 1991 having been carved out of the old Aniocha local government. It has a total of seventeen communities with its administrative headquarters in Issele uku. It is located west of the majestic River Niger. It lies between longitude $06^{0} 14^{1}$ and $06^{0} 30^{1}$ North of the equator and Latitude $06^{0} 18^{1}$ and $06^{0} 37^{1}$ East of the Greenwich meridian. It is bounded to the North by Edo 
state, to the West by Ika North-East Local Government Area of Delta State, to the East by Oshimili North local government area of Delta State and to the South by Aniocha South local government area of Delta State.

Aniocha North had a population of 104,711 by the 2006 population census. The towns that make up Aniocha North include; Issele-uku, Issele-azagba, Issele-mkpitime, Onicha-ugbo, Obior, Onicha-olona, Onicha-uku, Ugbodu, Ukwunzu, Ubulubu, Ogordor, Ugboba, Idumuogo, Obamkpa, Idumuje-unor, Idumuje-ugboko and Aniofu. Four of these communities, (Issele-uku, Issele-azagba, Issele-mkpitime, Onicha-ugbo) are enjoying urban status and are more affected by this waste management concerns. Most other communities have shown all the potential attributes to develop into major urban centre in the next few years. The people of the area are predominantly peasant farmers with low income literacy levels except for Issele-uku, the headquarter, Onicha-ugbo, Issele-mkpitime and Issele-azagba that are already grown into urban.

\subsection{Status}

Aniocha North local government has a tropical climate with two distinct seasons, the dry and wet seasons. Average rainfall is between $1800 \mathrm{~mm}$ and $3000 \mathrm{~mm}$. average temperature is between $25^{\circ} \mathrm{C}$ to $32^{\circ} \mathrm{C}$.

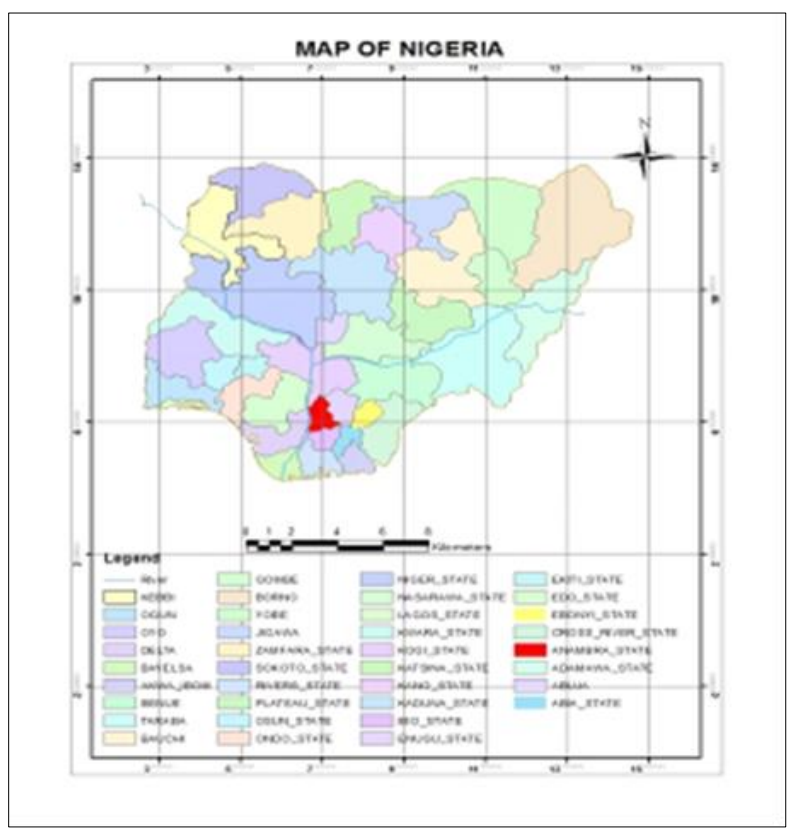

Figure 1a Map of Nigeria showing Delta State

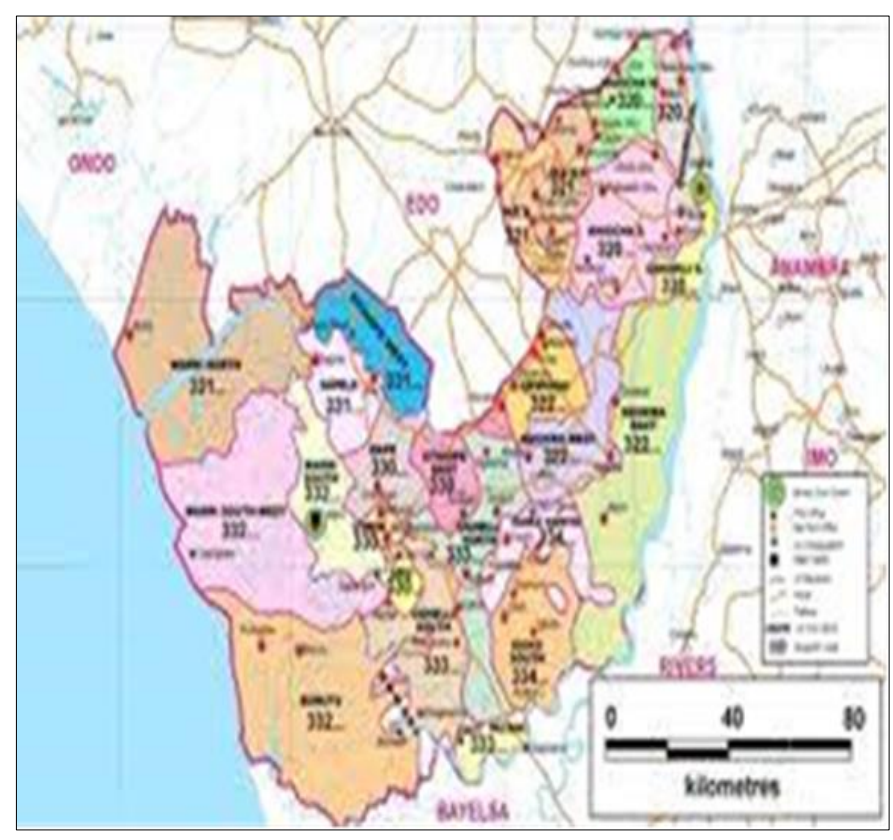

Figure 1b Map of Delta State

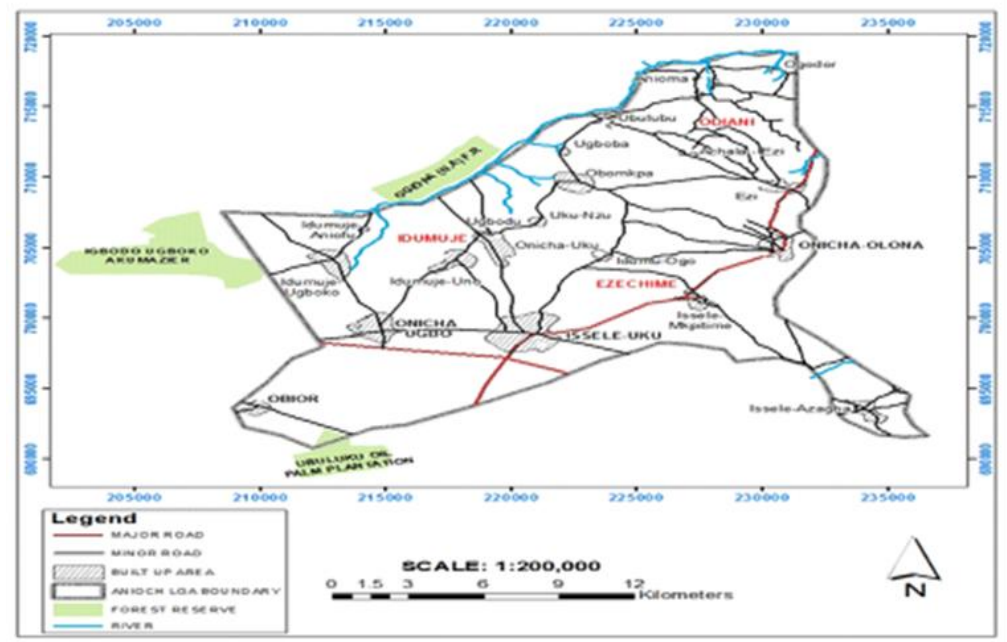

Figure 1c Map of Aniocha North LGA (Study Area) Source: Ministry of lands and survey asaba, Delta State 
The vegetation ranges from mangrove swamp along the coastal region and rain forest in the other places. Most of the communities are highly susceptible to erosion due to its nature of topography which is steeply particularly in the northern part of the local Government area.

The local government is situated on a highland and covered with clayey brick-red soil. Some traces of solid rock can be found in the towns located at the extreme north of the local government. The topography of the towns at the extreme north is also steeply and they are properly drained towards the north by river Ohe which is a tributary of the River Niger. River Ohe is actually the boundary line between Aniocha North and the neighboring Edo state and runs through the entire northern corridor of Aniocha North local government. Consequently, most of the communities on the northern part are highly susceptible to erosion due to the steeply nature of the topography around that area.

Aniocha North has a tropical climate with two distinct seasons, the dry and wet seasons. The wet season comes from about April/May and ends about October/November of the same year while the rest is the dry weather /harmattan period. Average rainfall is between $1800 \mathrm{~mm}$ and $3000 \mathrm{~mm}$.

\section{Methodology}

The main data used for this study is the $90 \mathrm{~m}$ resolution Shuttle Radar Topographic Mission (SRTM DEM) of the study area which was extracted from United State Geological Survey (USGS) and the topographic map of the study area on scale of 1:50,000. ArcGIS 10.2software (which includes the Spatial Analyst, Hydrological modelling extension and 3D Analyst extensions tools) was used for the analysis.

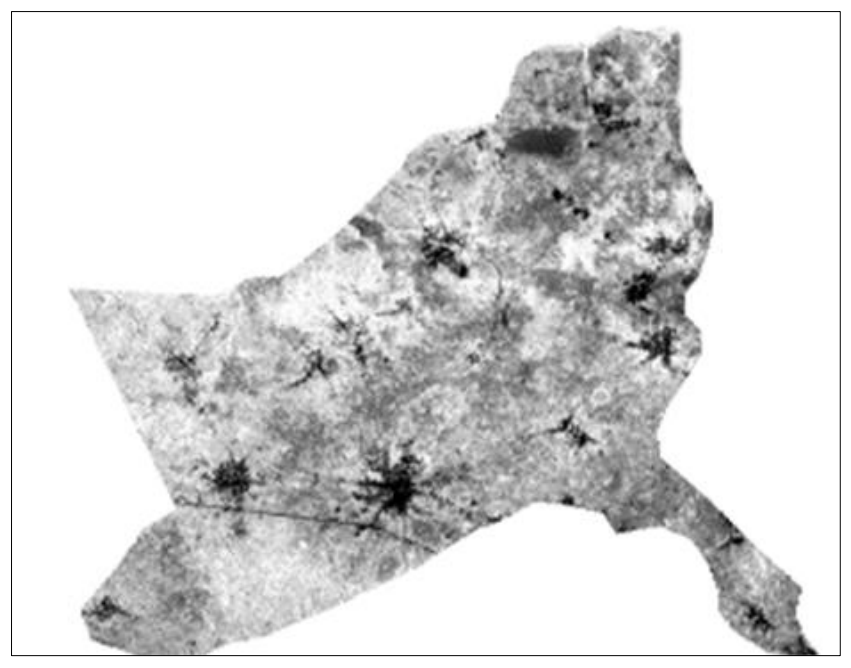

Figure 2 SRTM correction in Arc-Map

The SRTM data was geometrically rectified and projected into UTM, WGS-1984 datum, 32N zone projection system, so that errors can be minimized in GIS platform. ArcGIS 10.2 has been used for the digital analysis of remotely sensed data and was geometrically corrected and resampled using the toposheets of the study area as reference. The SRTM was also corrected to remove tree offsets to get the true surface heights (8). To achieve this, NDVI classification calculation was done to find the different vegetation heights. We have used such classification parameters of NDVI map to form the map with adjustments for vegetation height (considering the types of vegetation, present in the study area) in DEM. With this, we achieved the new DEM with adjustments for vegetation height (See figure 2).

The SRTM comes with errors that must be corrected to be sure to get correct values of data generated from them. Notable among the errors are the vegetation height or tree offset removal and the fill sink. Most DEMs will have sinks, or cells that are lower than all surrounding cells. Some sinks are natural parts of the landscape (ponds), while others are due to errors present in the DEM. In order to model flow all sinks in the DEM must be filled. The fill sink menu in the hydrological menu was used to carry out this correction. 


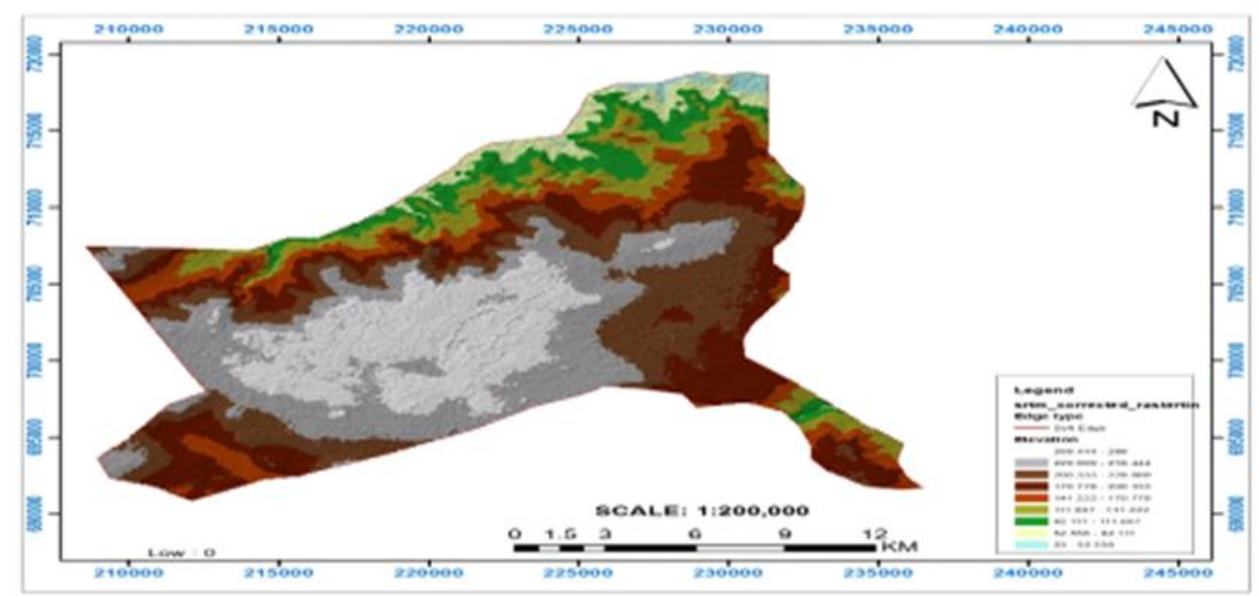

Figure 3 Filled Sink SRTM DEM

\subsection{Terrain Variability Determination}

The following topographic and hydrological products were derived from the SRTM:

\subsubsection{Contour map}

A contour line is an imaginary line which connects points of equal elevation. Contour maps are extremely useful for various engineering works. It helps find out the nature of the ground to identify suitable site for the project works, finding out depth of cutting and filling, locating bunds, dams and also to find out flood levels.

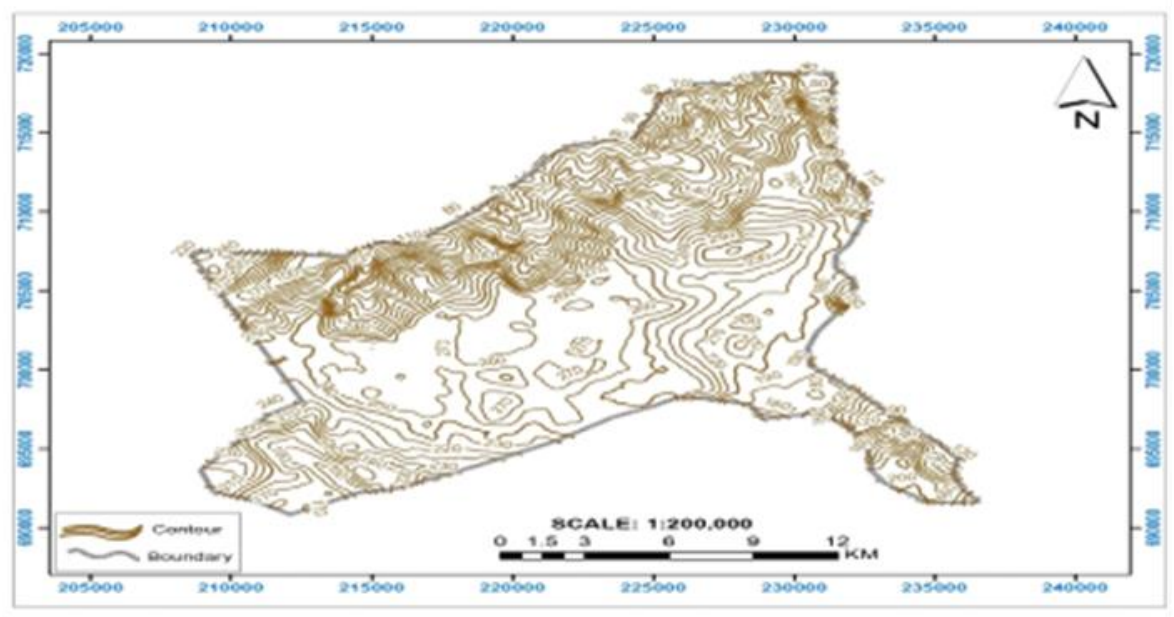

Figure 4 Contour map of the study area

In deriving contours from the arc-map, the following steps were followed:

In Arc-Map, click the 3D Analyst menu on the toolbar, point to Surface Analysis, and click Contour. Click the drop-down arrow and click on the surface from which you want to derive contours. Type the contour interval. Optionally, specify a $z$-factor. The z-factor is used to adjust the units of the data. For example, if you have data in meters and you want to produce contours in feet, you could use a z-factor of 3.28. Finally browse to the location where you want to save the contours and type a name for them and click OK to produce the contour map as shown in figure 4.

\subsubsection{Slope map}

A slope map is a topographic map showing changes in elevation on a highly detailed level. Architects, landscape designers, and water control planners use a slope map to evaluate a particular site. One of the most valuable uses of a map is to predict the flow of water. Ground water can cause heaving and shifting of buildings and parking lots. Runoff from storms can also damage property. A slope map may also indicate the placement of utility lines and their depth. 
Generation of the slope map with the software took the following procedure - from the Spatial Analysis Tool, click on Surface, click on Slope and an interface called Slope Dialogue Box will appear. Select the projected SRTM into the input raster box. The output was set to degrees so that the slope will be in degrees. In this case the z-factor was left as the default " 1 ". Click OK to produce the slope map. The slope of the study area is shown in figure 5.

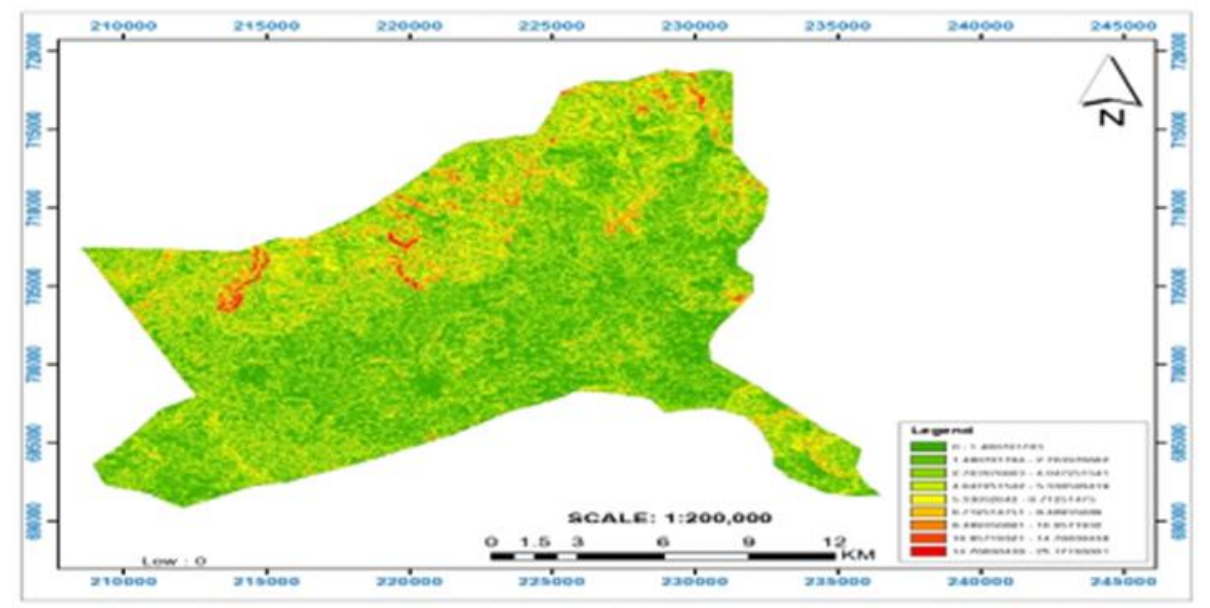

Figure 5 Slope map of the study area

\subsubsection{Flow direction}

Flow direction is important in hydrologic modelling to determine the paths of water movement. Flow direction is determined by finding the direction of steepest descent from each cell.

\begin{tabular}{|l|l|l|}
\hline 32 & 64 & 128 \\
\hline 16 & & 1 \\
\hline 8 & 4 & 2 \\
\hline
\end{tabular}

Figure 6 Flow direction encoding

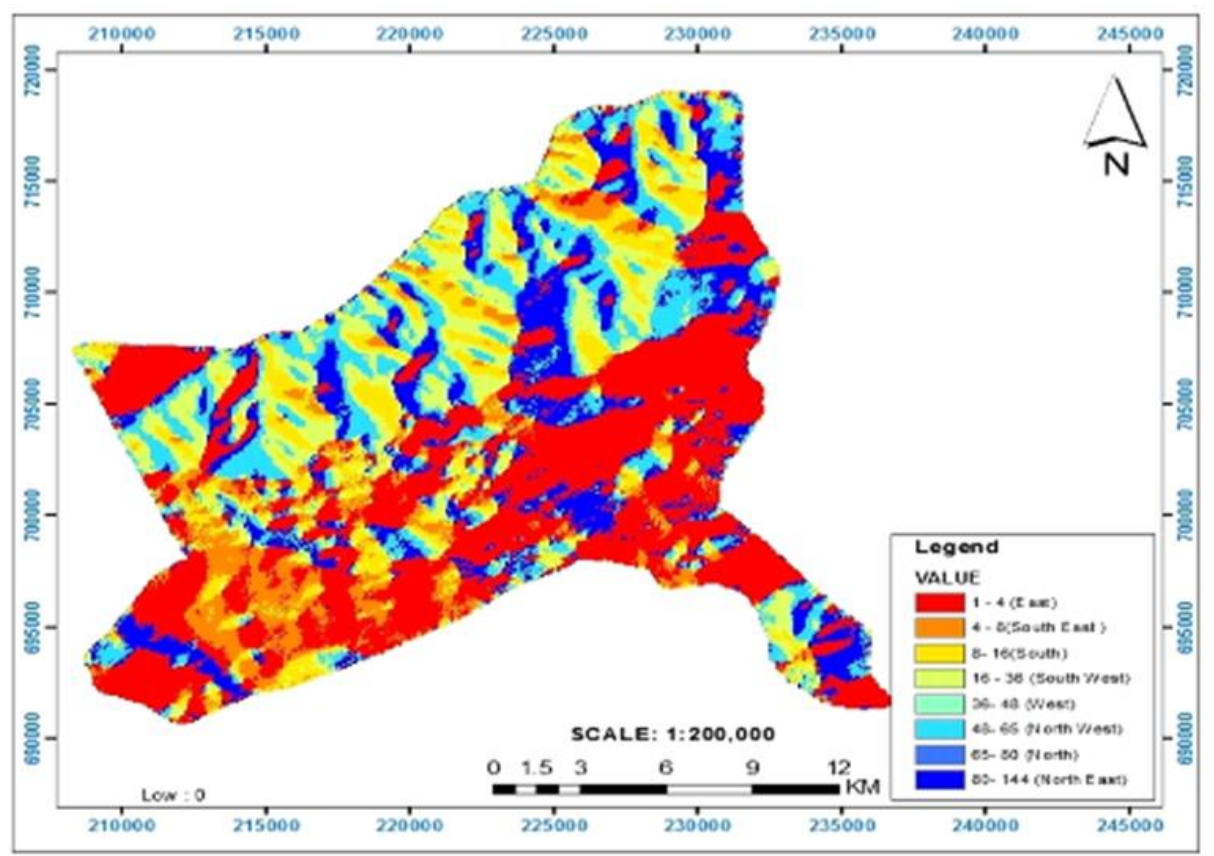

Figure 6 Flow direction map 
Flow direction is what is ultimately used to compute the watershed for a given outlet. The procedure to obtain Flow direction is as follows: From the Hydrology menu choose Flow Direction. Select nedfill as the input surface. Save the output raster in the $\backslash$ HydroMod $\backslash$ Data directory as flowdir. Click OK. This function is used to identify the water flow direction on a surface, or identify the steepest descending direction of each cell in a DEM. The 8 cells surrounding the central cell are coded by the powers of 2 , from the right of the central cell in figure 6 .

The cells are coded as 2 to the power of $0,1,2,3,4,5,6,7$, that is $1,2,4,8,16,32,64,128$, thus represent the water flow direction of the central cell to be east, southeast, south, southwest, west, northwest, north and northeast, as the image below shows. Every central cell's water flow direction is determined by one of the eight values. For example, if a central cell's water flow direction is west, it will be given the value 16. The flow direction map derived from the SRTM is shown in figure 6.

\subsubsection{Flow Accumulation}

Flow accumulation is defined as the accumulated number of cells upstream representing the upstream watershed area. It is calculated based on the flow direction grid. The flow accumulation grid records the number of cells located upstream of each cell which will contribute drainage area to each cell. Flow accumulation is not a step in delineating watersheds, but it does aid in ensuring that the outlet used to compute the watershed falls on cell that receives a substantial amount of flow from upland cells.

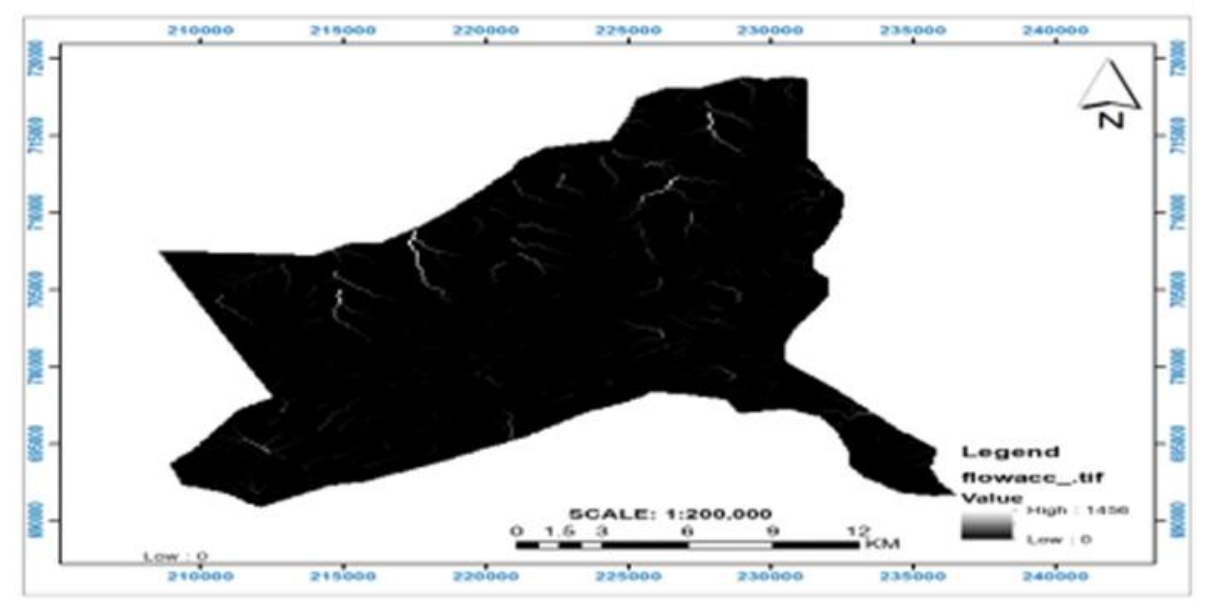

Figure 7 Flow Accumulation map

The basic thoughts of Flow Accumulation are supposing that there is one unit of water in each cell of the raster data and calculate the accumulated flow of each cell through the Flow Direction Map. It is calculated through flow direction. The flow direction raster data derived in from the SRTM was used to produce the flow accumulation map as shown in figure 7.

\subsubsection{Stream Power Index}

Stream power index (SI) considers both a local slope geometry and site location in the landscape combining data on slope gradient and catchment area:

$$
S I=1 \mathrm{n}(\mathrm{CA} \cdot \tan \mathrm{G})
$$

where CA and G are catchment area and slope gradient, respectively.

Stream power index can be used to describe potential flow erosion at the given point of the topographic surface. As catchment area and slope gradient increase, the amount of water contributed by upslope areas and the velocity of water flow increase, hence stream power index and erosion risk increase. 


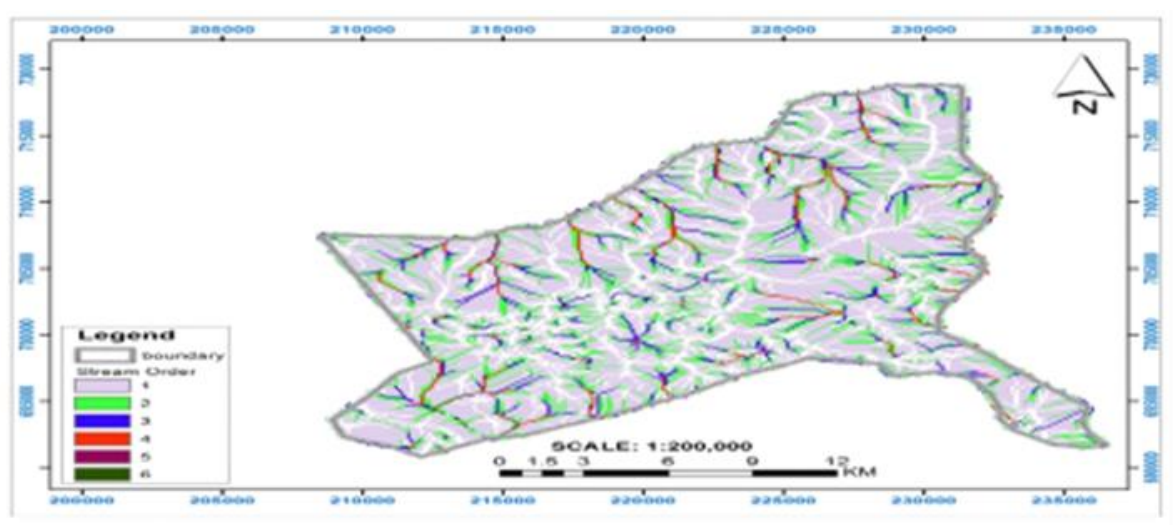

Figure 8 Stream Power index produced with ArcGIS software

\subsection{Analysis of Result}

For the contour map, widely spaced contour indicates flat surface, closely spaced contour indicates steep ground and equally spaced contour indicates uniform slope. The slope map indicates the deepest green areas to show the flattest terrain while the deepest red portions reveal the steepest part of the study area.

The flow direction is used to identify the water flow direction on a surface, or identify the steepest descending direction of each cell in a DEM and all the hydrology analyses need Flow Direction as a reference. The flow accumulation is calculated from the flow direction. The Flow accumulation operation performs a cumulative count of the number of pixels that naturally drain into outlets. The operation can be used to find the drainage pattern of a terrain and as input the operation uses the output map of the Flow direction operation.

Stream Power Index is the rate the energy of flowing water is expended on the bed and banks of a channel. The stream power index is the product of catchment area and slope and could be used to identify suitable areas of soil conservation measures to reduce the effect of concentrated surface runoff.

\section{Conclusion}

The shape of the earth's surface determines how water flows. Hydrology analysis provides a useful method for describing the physical features of the earth surface. You can model the flow of water and perform quantitative analysis on a DEM data. Hydrology analysis can extract the information about where water comes from and where it is going across on any cell of a raster data. DEM hydrology analysis model can be used to identify the extent of flood, position the pollution resource of a river, and forecast how changes in that area may affect that flow. This is useful in many fields, such as regional planning, agriculture, and forestry. All the hydrology analyses need Flow Direction as a reference. Flow across a surface will always be in the steepest down-slope direction. Once the direction of flow is known it is possible to determine which and how many cells flow into any given cell. This information is used to determine watershed boundaries and stream networks.

As part of ArcGIS hydro tools, we have used the Flow Direction tool to create a new grid that contains the direction that each of the cells in the grid flows into. The Flow Accumulation tool creates a new grid that contains the number of cells that contribute runoff to a cell in the grid.

\section{Compliance with ethical standards}

\section{Acknowledgments}

Thanks to Prof. Joel Igbokwe and Prof. Ebele Emengini for their support, guidance and input into this paper. All Authors read and approved the paper.

\section{Disclosure of conflict of interest}

There is no conflict of interest regarding the research, authorship and publication of this paper. 


\section{References}

[1] Zebker HA, Goldstein RM. Topographic mapping from interferometric synthetic aperture radar observations. J. Geophys. Res. 1986; 91: 4993-4999.

[2] Massonnet D. Satellite radar interferometry, Sci.Am. 1997; 276.

[3] Madsen SN, Zebker HA. Imaging radar interferometry, in Principles and Applications of Imaging Radar. Manual of Remote Sensing. John Wiley. 1998.

[4] Rosen PA, Hensley S, Joughin IR, Li FK, Madsen SN, Rodriguez E, Goldstein RM. Synthetic aperture radar interferometry. Proc. IEEE. 2000; 88: 333-382.

[5] Farr TG, Rosen PA, Caro E, Crippen R, Duren R, Hensley S, Kobrick Paller M, Rodriguez R, Roth L, Seal D, Shaffer S, Shimada J, Umland J, Werner M, Oskin M, Burbank D, Alsdorf D. The Shuttle Radar Topography Mission. 2007.

[6] Pike RJ. The geometric signature: quantifying landslide terrain types from digital elevation models. Mathematical Geology. 1988; 20(5): 491-510.

[7] Moore ID, Grayson RB, Ladson AR. Digital Terrain Modelling: A review of hydrological, geomorphological and biological applications. In: K.J. Beven and I.D. Moore (eds.). Terrain Analysis and distributed Modelling in hydrology. J.Wiley \& Sons. 1991.

[8] Moore ID, Gessler PE, Nielsen GA, Peterson GA. Terrain Analysis for Soil Specific Crop Management. In: Soil Specific Crop Management. ASA-CSSA-SSSA. 1993

[9] Weibel R, Heller M. Digital terrain modelling. In: Maguire, D.J., Goodchild, M.F., Rhind, D.W. (Eds.), Geographical Information Systems, vol. 1. Longman, Harlow. pp. 269-297. 1991

[10] Miller, C. L, Laflamme RA. The Digital Terrain Model-Theory and Application. Photogrammetric Engineering, Vol. XXIV, No.3, p. 433, June 1958. 